\title{
FLASH CARD MEDIA UTILIZATION TO IMPROVE STUDENT ACTIVITY AND LEARNING OUTCOMES OF FAUNA DISTRIBUTION SUBTOPIC IN CLASS XI IPS I SMA XIN ZHONG SURABAYA
}

\author{
Felisia Ferra Ristanti ${ }^{\mathbf{1}}$ and Fajar Arianto ${ }^{1}$ \\ ${ }^{1}$ Department of Educational Technology, Postgraduate, Universitas Negeri Surabaya, \\ Indonesia \\ Email: felisia.17070905012@mhs.unesa.ac.id
}

Received 18 March 2019/ Revised 15 May 2019/ Accepted 27 May 2019/ Published 1 August 2019

\begin{abstract}
The purpose of research to determine and describe whether the concept of flash card utilization is able to increase students activity students in learning in Geography subject. Though geography is a very important subject, particularly in determining the ample number of fauna found in Indonesia, which is even categorized as an endemic fauna. In addition, the manner in delivering subtopic which is considered monotonous by relying solely on reading books and summarizing what they have read are two things that are not surprising. Hence, those two facts encourage students not perform geography lessons enthusiastically. Considering the problems that occur, therefore I am interested in engaging the learning media "Flash Card" in delivering Subtopic of fauna distributions, especially in Indonesia. In each of these Flash Cards there is information regarding the fauna, starts from the picture, name, location of the distribution area, and animal characteristics. After performing the learning process engaging Flash Cards, students were divided into several groups and present Indonesia map along with regions name in front of the class. Then, the teacher would provide some questions related to the fauna characteristics and the groups were asked to answer questions by mentioning names and showing the origin of the fauna asked in the map. During this learning, students will likely compete againts other groups, but happened to be a pleasant circumstance without pressure. And at the end of the chapter, students will take a written test related to fauna distribution subtopic. The final result after applying the media "Flash Cards" turned out to be succeesful in improving student learning outcomes, especially upon fauna distribution subtopic in Indonesia at class XI IPS 1 SMA XinZhong Surabaya. As many as 28 students out of 36 students who did not accomplishminimum standard of 75 points, after engaging the media "Flash Card" they decreased up to only 3 students who did not meet the minimum criteria. Thereby, this result indicates that "Flash Card" mediautilization helps students to understand properly, embrace the subtopic adequately, and assist students to obtain better grades.
\end{abstract}

Keywords: Geography Subject, Flash Card, pretest, posttest 


\section{Introduction}

Geography is one of the subjects provided in the high school level and alesson that is plotted as a national exam subject for Geography specialization. Significant geography lessons are delivered to students in order to assist themin developing and providing knowledge toward everything related to the condition of the earth, namely social, natural, economic, political, and health. Hence, students would get insight of these conditions appropriately in term of daily life.

But unfortunately, most students are reluctant to learn and examine geography lessons due to broad scope of the subtopics and most of them are quite distant and unreachable into their reach. This encourages students being hesitant inexamining geography lessons, especially Fauna Distribution in Indonesia. Subtopic of fauna distributions is assumed to be difficult for students, since some students are required to be able to obtain understanding regarding the names, characteristics, and location of each fauna in Indonesia. This will certainly reduce their passion for the nation as part of the effort to preservemotherland assets in the form of Fauna variety.

Based on the issue mentioned above, the teacher is expected to be able to provide the best solution to establish geography lesson to be more enjoyable and beneficial lessons for them. Teachers must be able to encourage and motivate students to enjoy geography lessons by providing appropriate and fun media for students, especially subtopic of fauna distribution. By applying the suitable media will likely fostering student learning passion, therefore students will be more understand regarding the subtopic.

A solution can be applied is media utilization, namely flashcard. It will help to increase students' interest in learning, as stated by Erwin Putra Permana (2015: 4) argues that the overall interest of studentsusing snake ladder media in cycles I, II and cycle II has increased.

Learning media is a tool that helps teachers to deliver subtopic more easily and effectively, hence students will obtain faster understanding towards subtopic given to them, in this case learning media is a tool for learning aids. One of the media that may support is a Picture card/Flash card. This factassociates to the research conducted by LailatulMaghfiroh (2013: 14) stating that media engagement in the flashcard learning process is very significant. The average student learning outcomes increased by 11.4, namely from 76.4 in the first cycle to 87.8 in the second cycle. Student learning accomplishness also increased by $24.3 \%$, namely from $69.6 \%$ in the first cycle to $93.9 \%$ in the second cycle. This statement is supported byFitri (2009: 12) which reveals that student learning outcomes increased from cycle I, to cycle II 
and from cycle II to Cycle III. The results of the learning process (affective) of the classical average value of the first cycle is 79.86 , cycle II is of 84.19 , and the third cycle is 87.64 after picture card media application.

Therefore, in term of this problem, the researcher conducts a study entitled "Flash Card Media Utilization to Improve Students Activity and Learning Outcomes of Fauna Distribution Subtopic in class XI IPS SMA Xin Zhong Surabaya.”

Table 1. List of Cycle I Pre-Test Values (before media)

\begin{tabular}{|c|c|c|c|}
\hline No & ID Student & Student Name & Pre-test (Cycle 1) \\
\hline 1 & 36160342 & Audrey Kowara & 72 \\
\hline 2 & 36160344 & Celine Angir & 65 \\
\hline 3 & 36160345 & Celine Morgan Gemiartha & 90 \\
\hline 4 & 36160346 & ChelseyWinardi & 44 \\
\hline 5 & 36160347 & Christopher Bertrand & 88 \\
\hline 6 & 36160348 & Felicia Catherine Kusuma & 66 \\
\hline 7 & 36160349 & Jessica Theodora & 89 \\
\hline 8 & 36160350 & KanayaAudyPhwa & 65 \\
\hline 9 & 36160351 & Kayla Soewito & 54 \\
\hline 10 & 36160352 & Kent Hartono Pranoto & 86 \\
\hline 11 & 36160353 & Kevin Christoval & 68 \\
\hline 12 & 36160354 & Kevin Tjokro & 56 \\
\hline 13 & 36160355 & Leonard Minarto Karman & 68 \\
\hline 14 & 36160356 & ReynerAwstenGonia & 62 \\
\hline 15 & 36160357 & Ryan William & 67 \\
\hline 16 & 36160358 & Victoria Britney Kairupan & 88 \\
\hline 17 & 36160359 & WirawanCipta & 67 \\
\hline 18 & 36160360 & YessikaVania & 70 \\
\hline 19 & 36160361 & Alexander JevanWinarjo & 56 \\
\hline 20 & 36160362 & Angelina Karen & 85 \\
\hline 21 & 36160363 & Celine & 40 \\
\hline 22 & 36160364 & Christopher Ibrahim & 66 \\
\hline 23 & 36160365 & Evangeline Chevonna & 77 \\
\hline 24 & 36160366 & Giovanna Jessica Karren & 85 \\
\hline 25 & 36160367 & Isabel ElginaPramana & 73 \\
\hline 26 & 36160368 & James Wijaya & 78 \\
\hline 27 & 36160369 & Javier Wibowo & 53 \\
\hline 28 & 36160370 & Justin Clement Leonard & 64 \\
\hline 29 & 36160371 & LaeticiaMcDonnelyLijiaZeng & 82 \\
\hline 30 & 36160372 & Leonard Chandra & 67 \\
\hline 31 & 36160373 & LysiaValentinaGani & 65 \\
\hline 32 & 36160374 & Michelle Stephanie Wijaya & 70 \\
\hline
\end{tabular}




\begin{tabular}{|l|lll}
\hline 33 & 36160375 & Roger KeijiKurniawan & 67 \\
\hline 34 & 36160376 & Sabrina Vanessa Pradibta & 60 \\
35 & 36160377 & Steven Winner Faith & 40 \\
36 & 36160378 & Vicky Jonodihardjo & 60 \\
\hline
\end{tabular}

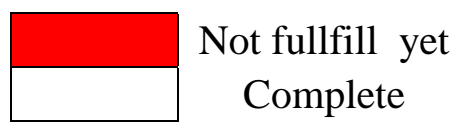

The purpose of research to determine and describe whether the concept of Flash card utilization is able to increase students activity students in learning in Geography subject, especially $11^{\text {st }}$ grade IPS 1 students of SMA Xin Zhong Surabaya and to determine and describe whether the concept of Flashcardutilization is able to improve student learning outcomes in Geography subject, especially $11^{\text {st }}$ grade IPS 1 students of SMA Xin Zhong Surabaya.

\section{The Methods}

\subsection{Subject}

This study engages classroom action research. The subjects of the study were 36 students of IPS XI IPS I SMA Xin Zhong Surabaya. The subject selection was considering average grade level of geography subject the XI IPS 1 between two other classes.

\subsection{Data source}

This study engages primary data sources, which are directly taken in the field (class).

\subsection{Data collection technique}

Data collection technique engaged in this study is observation towards the students' score of fauna distributions subtopic using the media "Flash Card." This amis to determine the development of students' understanding within subtopic through the provision of written tests. The test was given 2 (two) times at the beginning of the meeting (pretest) and after the media application of "Flash Cards" (posttest).

\subsection{Place and Learning Schedule}

a. Place: Research wasconducted in SMA Xin Zhong Surabaya

b. Schedule: Learning wasperformed during geographic and gradual subjects. 
Felisia Ferra Ristanti and Fajar Arianto /GEOSI Vol 4 No 2 (2019) 90-104

Table 2. Place and Learning Schedule

\begin{tabular}{cccc}
\hline & Date & Time & Cycle \\
\hline 1 & Monday, October 8, 2018 & $3-4$ & I \\
2 & Monday, October 29, 2018 & $3-4$ & II \\
\hline
\end{tabular}

\section{Results and Discussion}

\subsection{Respondents' Initial Conditions}

The condition of the research subjects prior to the treatment/treatment was as follows:

a. Students experience learning difficulties, especially in understanding the concept of learning. This is indicated by students ability to answer questions given by teacher during learning process was relatively low.

b. The ability to obtain basic competencies that have not been satisfied. This shows that the teaching conditions established by teachers were less interested for students which affected learning oucomes. There was few teaching techniques performed by the teacher tend to maintain classical method. It affects students' interest to learn.

c. Tasks completed by students could notmeet the factualmatter of the task. This shows that the students level abilitywas still relatively low, because both the conditions of student interest and the learning process undertaken by the teacher wererelated upon actual circumastanceand students conditions.

d. The results of student learning tests are relatively low. This is showed by the results of learning outcomes achievements which that were not meet the expected minimum standard of 75 .

\subsection{Description of Cycle}

a. Cycle I

1) Planning

- Arranging learning planning (Syllabus and lesson plan/RPP)

- Identifying learning resources

- Providing facilities needed

- Preparing the matter of the pretest 
2) Action

- Initial activities: Student perceptions of the subtopic were to be discussed, by asking what they had known about the definition of fauna, and trying to identify the kinds of fauna in the surrounding environment, then conveying the learning objectives.

- Core Activities: Teacher explained the outline of fauna distribution subtopic in Indonesia, then providedquestions about the subtopic that has been delivered

- Closing activity: Teacher performed the pretest

3) Observation

Table 3. Results of students observations and Geography learning outcomes of SMA Xin Zhong Surabaya cycle I

\begin{tabular}{cc}
\hline Information & Cycle I \\
\hline The average percentage of students activity & 72.79 \\
The average percentage of students result & 68.64 \\
\hline
\end{tabular}

The graph of students observations and learning outcomes in the first cycle are presented as follows:

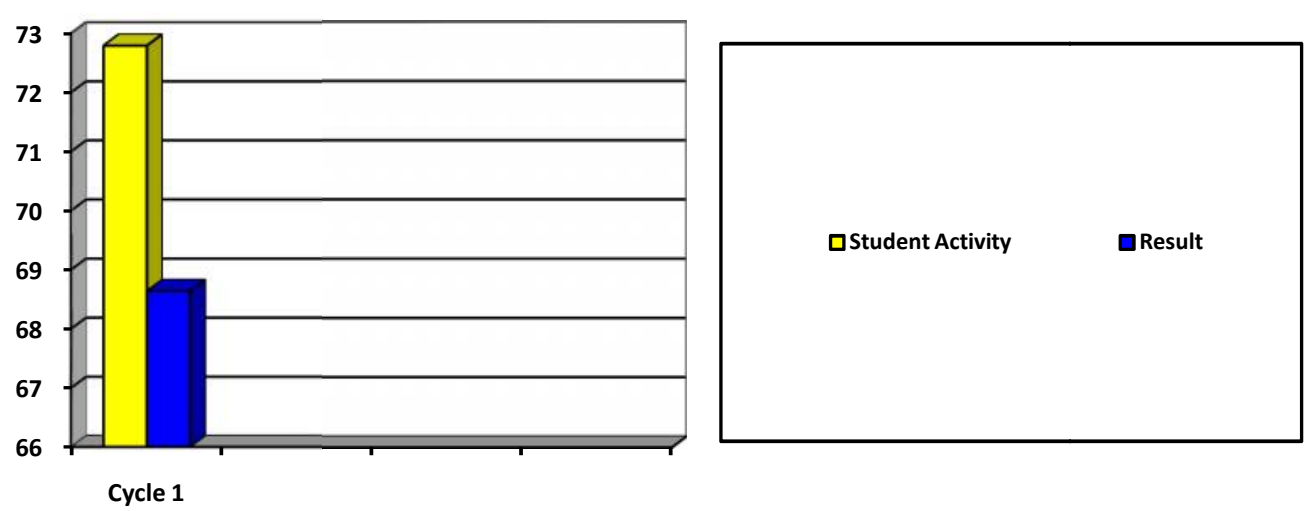

Figure 1. Graph of students observation results and Geography learning outcomes of SMA Xin Zhong Surabaya on cycle I 


\section{4) Reflection}

Learning in the first cycle was considered insufficient which was indicated through the number of students who have not met the minimum criteria.

b. Cycle II

1) Planning

- Arranging learning plans (Sylabus and RPP)

- Identifying learning resources

- Determining measures must be taken to examine the subtopic

- Preparing the means needed, in this case the learning media "Flash Card"

- Preparing the posttest questions

2) Action

Initial activity: Apperception of students by repeating the subtopic that was discussed last week, by asking what was known about the meaning of fauna. And then attempting to identify the kinds of fauna that remains in the surroundings and some contents that were discussed last week, then conveying the learning objectives .

3) Core activities

- Students were divided into 6 groups, the position of each group surrounds the board which had a map of Indonesia,

- Teacher provided learning media "Flash Cards" containing subtopic of the Fauna distribution in Indonesia and prepared maps of Indonesia in front of the class along with map descriptions (city names, etc.)

- Each group was given as many as 20 Flash Cards that proposed information regarding fauna in Indonesia (pictures, names, locations of distribution areas, and animal characteristics), and learn each item in a group

- Teacher delivered questions to students about the location of the fauna distribution area by pointing directly to the map, with the fastest system students would get an additional point

- Last, a question and answer session was conducted regarding the subtopic that has been delivered

4) Closing activity: Teacher carried out the posttest

5) Observation 
The results of students activities observation and evaluation of the learning outcomes in the second cycle can be seen in the following table

Table 4. Results of students observation and students Geography learning outcomes of SMA Xin Zhong Surabaya cycle II

\begin{tabular}{cc}
\hline Information & Cycle II \\
\hline The average percentage of students activity & 83.13 \\
The average percentage of students result & 79.33 \\
\hline
\end{tabular}

Then the results are presented in the form of graph. The results of students observation and students learning outcomes in the second cycle can be seen below;
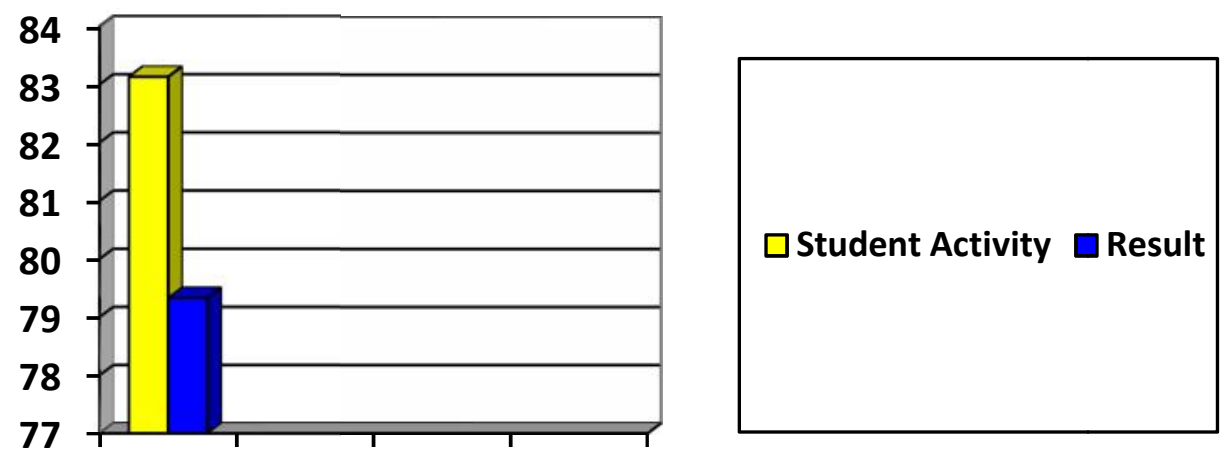

\section{Cycl e 2}

Figure 2. Graph of students observation and students learning outcomes of Geography subject in SMA Xin Zhong Surabaya cycle II

Questionnaires propose 10 statement items displaying students responses to the learning models using mind mapping methods or concept maps. The statement items within the questionnaire are as follows:

1. Geography is attractive and saturating.

2. I get excited during learning process by engaging a learning model with mind mapping methods or concept maps.

3. The classroom atmosphere is more composed and more conducive/supports the learning process.

4. Makes it easier for me to understand subject matter and I feel better at mastering Geography. 
5. Growing creativity and thinking power in students.

6. I become more courageous in expressing opinions or answers

7. I like to do assignments from the teacher.

8. Students are active in groups and work together in answering quizzes

9. I am pleased to work on Geography questions.

10. With this method my Geography score has increased.

Furthermore, to be clearer and easier in identifying students' responses to each student response, there are categories. Which are strongly agree (SS), agree (S), disagree (TS), and strongly disagree (STS), these categorieswere analyzed descriptively in terms of percentages for each category. The form of a percentage chart for each category of students' responses questionnaire to the learning model with the Flash Card can be seen in the following picture:

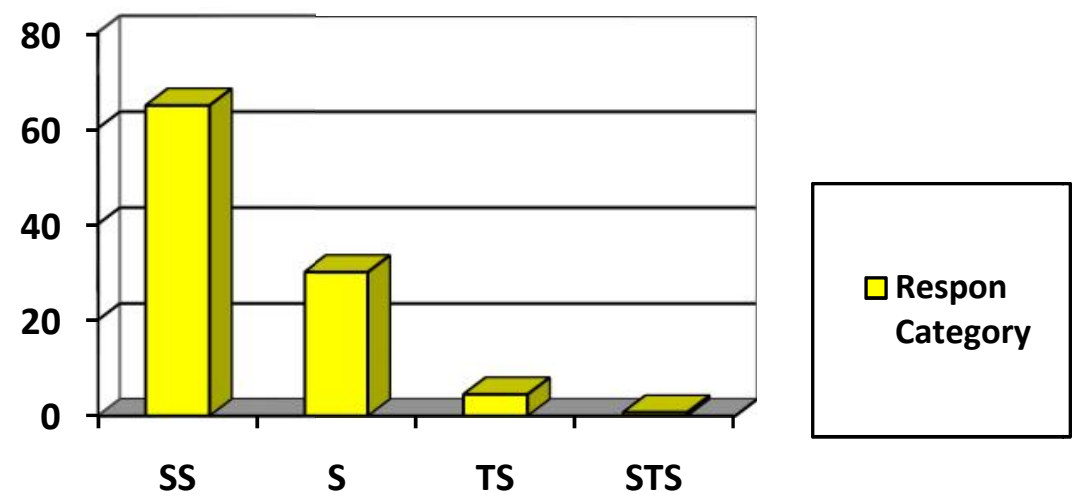

Figure 3. Graph percentage of each category towards student responses to the learning model engaging the Flash Card.

\subsection{Reflection}

The results obtained during the implementation of the second cycle are presented below;

(1) Improvement of the student learning outcomes basedon student competency analysis test values indicates the percentage of the average value of $68.64 \%$ in the first cycle and $79.27 \%$ in the second cycle with completeness level of the first cycle of $79.17 \%$ and cycle II amounting to $97.8 \%$. The percentage of average value and class accomplishment has increased by more than $10 \%$. The number of students who completed, compared to the first cycle result, students learning outcomes were increased in the second cycle.Whereas, in the 
second cycle it was only asingle student was considereduncomplete. Classical accomplishment has met the predetermined indicator of $80 \%$ and, (2) the most responses of students to learning are agree (S) with a percentage of $61.3 \%$, strongly agree (SS) $28.7 \%$, disagree (TS) $8.9 \%$, and strongly disagree (STS) 1, 1\%. The number of percentages strongly agree and agree gain 90\% largercompareto the disagree and strongly disagree category. Students activities and learning outcomes improvement of class XI IPS 1 SMA Xin Zhong Surabaya in the form of tables and graphs can be observed as follows:

Table 5. Students activity and learning outcomes improvement of class XI IPS 1 SMA Xin Zhong Surabaya.

\begin{tabular}{lcc}
\hline Information & Cycle I & Cycle II \\
\hline The average Prosentase of student activity & 72.79 & 83.13 \\
The average Prosentase of student result & 68.64 & 79.33 \\
\hline
\end{tabular}

Graphical form of students activity and learning outcomes improvement can be seen as follows:

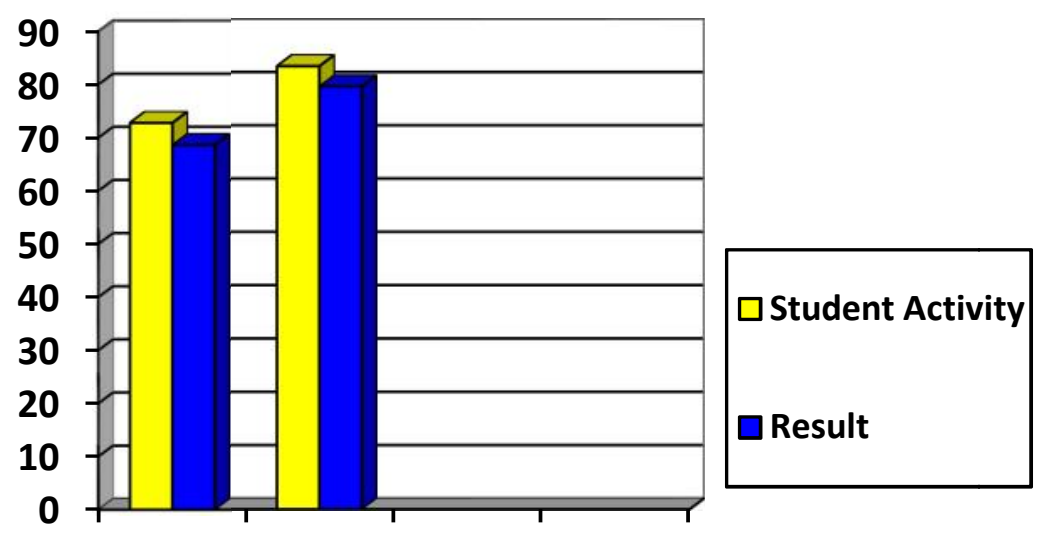

Cycle 1 Cycle 2

Figure 4. Graphical form of students activity and learning outcomes improvement

The learning model with the flash card method allows students to develop more active manner in problem solving, the accuracy of scientific thinking, interacting in groups, and understanding the material through direct demonstration. Based on observational data analysis in the first cycle, the closing section was not implemented due to the lack of learning by using the Flash Card. For this reason, implementation planning for Flash Card contains questions and answers that must be solved well in the second cycle. 
There is still insufficient of shared thinking activities in the first cycle, possibly because students were not quite familiar towards learning which emphasizes the importance of interacting, convincing others, and equating perceptions. Another reason is the deficiency of teacher guidance in term of nurturing the significant cooperative working (social skills) within groups. The teacher only guided the demonstration and answers the quiz.

Learning cycle results of the second cycle performs suitable results better than cycle I. Intensive guidance both in terms of analyzing and answering each question in the Flash Card in groups and teaching social skills (by reminding them to think together), encouraging activities to demonstrate, think cooperatively (interact, convincing each member, equating perceptions), and answering questions quite prominently. These activities are notable points in student activities. Thereby, student activities criteria increases from suitable criteria in the first cycle to be very suitable in cycle II. These facts imply that students performance have been above the specified performance indicator which is suitable. In addition, the positive impact is student activity and student learning outcomes have improved.

The incompleteness of student learning outcomes in cycle I has to do with students who performed alone in learning Flash Cards or answer questions that were less heterogeneous and grouped. Thereby, there are groups of some students who were considered weaker than excellent students. Forms of questions were designed by researchers based on demonstrations relating to the concept, motivating students to concentrate on embracing the demonstration and listening to the questions.Thus, students tend to not making mistake in answering and also spurring students to think scientifically on the demonstrations presented. Hence, students were able to answer quiz questions in groups, later find out the answer through evidence of the demonstration that was displayed, then students' understanding upon material being taught was increasing.

Students understanding improvement has a direct effect on students' ability to work on competency test questions given, thus that it would possibly improve student learning outcomes. The students' incompleteness in the first cycle was encouraged by the fact which was students inability to understand and not yet accustomed to engage learning model using Flash Card, thereby they did not master the material taught. In cycle II students became more enthusiastic about learning, therefore there is an increase of students activities and students learning outcomes which also inclineslearning accomplishment level. Improvement occurs towards student activities and student learning outcomes from cycle I to cycle II.

The questionnaire used to determine students' responses to the learning model is Flash Card method which was disseminated to each student after the learning activity Concept map 
cycle II was carried out. According to the responses given by students, it can be concluded that the learning performance is rather new, students feel pleased to do lessons, quizzes are easier to understand, motivate to do tasks, feel ready to answer questions, more focus and think critically, and be more passionate. This shows that physics learning using the Flash Card learning model receives a positive response from students.

During teaching and learning activities, learning outcomes obtained by students can be influenced by the presence of the learning media. Gagne \& Ely (in Arsyad, 2002 : 83) argue that the media if defined broadly are human, material, or events that build conditions, which causes students to be able to obtain knowledge, skills, or attitudes. Media has a significant role in building students' understanding and knowledge more effectively and efficiently. One medium that can be used in studying Fauna diversity material is a picture card. Picture cards, or better known as flash cards, are small cards that display images, text, or symbol signs that remind or guide students to something related to that image (Arsyad, 2009 : 75).

According to the Indonesian Dictionary, cards are thick rectangular paper for various purposes. Cards are flat-field graphic media that comprise certain writings, images, and symbols. In term of learning media, cards can be made in various shapes and models. According to Mugiyanto (2007:57) cards include props that works to facilitate students in understanding a concept, thereby achievement results can be better, learning is more enjoyable and more effective.The benefits of picture card media in instructional processes according to Rohani (1997: 76) are "the delivery and explanation of information, messages, ideas and so on without significant use of the verbal languages, but it could provide more impression".

Based on the findings and reflections results which can be analyzed and concluded by the author, it is necessary to reflect themselves to know firsthand the success of using the Flash Card learning media, as indicated by an increase in learning outcomes within testpriorto media usage (cycle I) and test following media use ( cycle II). This results associate to the research studytittled'Influence of Drawing Card Media on Student Learning Outcomes in Mushroom Materials In High School' by WindaAstuti, LailiFitriYeni, EkaAryati (2013:23) there are differences in learning outcomes of students taught using pictorial card media and taught without using media picture cards on mushroom material in class X of SMA Negeri 1 Ketapang.

The decent learning outcomes of students in the experimental class after picture card media utilization that possesses images and mushroom material, these images represent the concepts of mushrooms according to the learning objectives. The argument of students failure 
in achieving suitable grades in accordance with the minimum criteria,since students have not been able to receive the material properly, enjoy less, and were not ready to learn material that has never been obtained before. While the thing that makes the success of students in the second cycle (after the use of media) is the media engagement. It gave students the opportunity to discuss with group friends to establish answers to the questions from the Flash Card. In addition, students were ablelearn while competing with friends from other groups in examining answers. But, despite competing with friends between other groups, they could still learn casually and there was no pressure. There were 26 students who did not meet the minimum criteria of 36 students in total of the first cycle (before media use), all students could succeed well in increasing the learning value in the second cycle test after learning process engaging the Flash Card media. Based on the pretest conducted in the second cycle, the learning outcomes of students who obtained under the 75 (minimum criteria) were only 3 students from 36 students in a single class, and as many as 33 students had scored above the 75 (minimum criteria).

\section{Conclusion}

The provision of learning media in term of delivery of subtopic in effective learning to improve children's learning outcomes and understanding is increasing. Particularly due tostudents behavior tend to be enthusiastic when delivering subtopic in less monotonous according the teacher explains and everything is in the book only, but there should be some variations. A competitive but not pressing learning atmosphere and tends to be comfortable circumstance are two things that generate improvement of students' enthusiasm in taking lessons and understanding them. Students in general will be very interested and willing to try if only the subtopic taught is given in a different way and not in monotonous way. Discussion activities with group by giving opinions were also effective in completing students' knowledge, hence the right and expected conclusions were obtained. In addition, the bound between teachers and students themselves was also able to provide an injection of enthusiasm and motivation for students to want to learn. Teacher must be creative in delivering subtopic. There is a compulsory for variations in the media used to attract students' enthusiasm in taking lessons. Teacher should provide opportunities for students to participate as much as possible in the acquisition of value. Despite getting a value, students will indirectly add to the understanding of what they have asked and answered. According to the study result, it can be 
concluded that the Flash Card method is capable in improving GEOGRAPHY learning outcomes in Fauna Disttibution topic for students of class XI IPS 1 SMA XInZhong Surabaya. The daily repetition rate before the action is 55.71 rose to 68.64 in the first cycle and 79.33 in the second cycle. The average percentage of student activity before threatment is 60.43 increases to 72.79 in cycle I and 83.13 in cycle II.

\section{References}

Agung, A.A.Gede. (1998). Pengantar Evaluasi Pendidikan. Singaraja: STKIP Singaraja.

Anggarwati, A. (2014). Pengaruh Make A Match Berbantuan Media Kartu Gambar Terhadap Hasil Belajar IPS SD.Jurnal (diterbitkan).Universitas Pendidikan Ganesha

Astuti,W.(2013). Pengaruh Media Kartu Bergambar Terhadap Hasil Belajar Siswa Pada Materi Jamur di SMA.Jurnal (diterbitkan). Untan.

Dimyati \& Mudjiono. (2006). Hakikat Belajar dan Pembelajaran..Jakarta: Rineka Cipta

Depdikbud.(1995). Metodik Khusus Pengajaran IPS di SekolahDasar. Jakarta: Depdikbud

Handayani, F.(2009). Cooperative Learning Type Team Game Tournament (TGT) to increase the Learning Outcome of the Student of Class VII at SMP Negeri 1 PurwodadiPasuruan to Consept Kinds of Form the Earth Surface. Thesis, Geography Education Departement. Post Graduate Program, State University of Malang

Hidayat, M, et al. (2008). Development of Geography Education in Elementary Schools. Jakarta: Ministry of National Education.

Joni. (1984). Teaching and Learning Strategies. Jakarta: Ministry of Education and Culture

Maghfiroh, (2013).Penggunaan Media Flashcard untukmeningkatkanhasilbelajar IPS padaPembelajarantematik di SekolahDasar.Surabaya : PGSD Unesa

Ministry of Education and Culture.(1995). Special Methodology for Geography Teaching in Elementary Schools. Jakarta: Ministry of Education and Culture

Mugiyanto.(2007). Penggunaan Kartu Konsep untuk Meningkatkan Hasil Pembelajaran

Sejarah.Onlineat.http://jurnaljpi.wordpress.com/2007/ 11/14/mugiyanto.(2 Januari 2009).

Noor, J. (2010). Metodelogi Penelitian. Jakarta: KencanaPrenada Media Group.

Permana.(2015). Penerapan pembelajaran IPS dengan media ular tangga untuk meningkatkan minat belajar siswa. Kediri: Universitas Nusantara PGRI Kediri. 
Felisia Ferra Ristanti and Fajar Arianto /GEOSI Vol 4 No 2 (2019) 90-104

Rohani, A. (1997). Media Instruksional Edukatif. Jakarta: Rineka Cipta. 